\title{
Pemetaan Fungsi Kognitif Siswa SMP DENGAN Menggunakan Feuerstein's Instrumental Enrichment
}

\author{
Mochammad Amirudin ${ }^{1}$, Ijtihadi Kamilia Amalina ${ }^{2}$ \\ ${ }^{1}$ S2 Pendidikan matematika, Universitas Negeri Surabaya \\ ${ }^{2}$ S2 Pendidikan matematika, Universitas Negeri Surabaya
}

\begin{abstract}
ABSTRAK
Berpikir merupakan kegiatan yang paling utama ketika melakukan suatu hal. Berpikir selalu melibatkan kognitif. Penggunaan kognitif secara maksimal tentu melibatkan kehadiran dari fungsi kognitif. Kehadiran fungsi kognitif seseorang dalam menyelesaikan permasalahan matematika mengakibatkan berkembangnya fungsi kognitif seseorang tersebut. Penelitian ini merupakan penelitian deskriptif yang bertujuan untuk mendeskripsikan hasil pemetaan fungsi kognitif dan kemampuan matematika siswa. Subjek penelitian ini adalah siswa SMP kelas VIII sebanyak 32 siswa (15 laki-laki dan 17 perempuan). Data dikumpulkan dengan menggunakan metode tes dan wawancara. Instrumen yang digunakan dalam penelitian ini adalah instrument tes Feuersteins's Instrumental Enrichment (FIE) (pengorganisasian titik, pengelompokan, dan progress numeral) dan instrumen tes matematika. Hasil penelitian menunjukkan bahwa peta fungsi kognitif dan kemampuan matematika siswa dengan menggunakan FIE jenis Pengorganisasian Titik menunjukkan bahwa, sebanyak 32 subjek terbagi menjadi sebesar 18,75\% termasuk dalam kemampuan matematika tinggi, sebesar $71,875 \%$ termasuk dalam kemampuan matematika sedang, dan sebesar 9,375\% termasuk dalam kemampuan matematika rendah. Untuk Jenis Pengelompokan menunjukkan bahwa masingmasing sebesar $6,25 \%$ pada fungsi kognitif yang pertama dan kedua, termasuk dalam kemampuan matematika rendah. pada fungsi kognitif yang ketiga terdapat $6,25 \%$ termasuk dalam kemampuan matematika tinggi, 3,125\% termasuk dalam kemampuan matematika sedang, dan $78,125 \%$ termasuk dalam kemampuan matematika rendah. Sedangkan pada jenis Numerical Progression menunjukkan bahwa pada fungsi kognitif yang pertama sebesar $18,75 \%$ termasuk dalam kemampuan matematika rendah. sedangkan pada fungsi kognitif yang kedua sebesar $59,375 \%$ termasuk dalam kemampuan matematika tinggi, sebesar 3,125\% termasuk dalam kemampuan matematika sedang, dan sebesar 18,75\% termasuk dalam kemampuan matematika rendah.
\end{abstract}

Kata Kunci: Pemetaan, Fungsi Kognitif, Kemampuan Matematika, Feuerstein's Instrumental Enrichment.

\begin{abstract}
Thinking are the most important activities when do a something. Thinking always involves cognitive. The use of cognitive in maximally will involve attendance of cognitive function. The presence of cognitive function a person in mathematics problem thinking result the cognitive function of the someone developed. The
\end{abstract}


research is descriptive that aims to describe the result of mapping of students' cognitive function and mathematics ability. The subjects of this research were one class 32 students of $8^{\text {th }}$ junior high schools 2 Jombang (15 boys and 17 girls). Collecting data by using the test and interview method. This research used two instrument were Feuerstein's Instrumental Enrichment test (organization of dots, categorization, and numeral progression) and mathematics test. The result of this research showed that the mapping of students' cognitive function and mathematics ability by using Feuerstein's Instrumental Enrichment, Organization of dot test showed that from 32 subjects divided as: $18,75 \%$ in high mathematics ability", $71,875 \%$ in medium mathematics ability, and $9,375 \%$ in low mathematics ability. For Categorization test showed that $6,25 \%$ in first and second cognitive functions in low mathematics ability. For third cognitive functions, $6,25 \%$ in high mathematics ability, $3,125 \%$ in medium mathematics ability, and $78,125 \%$ in low mathematics ability. However, for Numerical Progression test showed that first cognitive function, $18,75 \%$ in low mathematics ability. In second cognitive functions, $59,375 \%$ in high mathematics ability, $3,125 \%$ in medium mathematics ability, and $18,75 \%$ in low mathematics ability.

Keywords: Mapping, Cognitive Function, Mathematics Ability, Feuerstein's Instrumental Enrichment.

\section{PENDAHULUAN}

Berpikir merupakan kegiatan yang paling utama ketika melakukan suatu hal. Tak ada sedikitpun kegiatan yang dilakukan oleh manusia tanpa melibatkan berpikir. Berpikir merupakan suatu aktivitas mental untuk membantu menformulasikan atau memecahkan suatu masalah, membuat suatu keputusan, atau memenuhi hasrat keingintahuan [1]. Berpikir mengaitkan antar pengetahuan yang mencakup segala konsep, gagasan, dan pengertian yang telah dimiliki atau diperoleh seseorang [2]. Dalam hal ini tampak bahwa berpikir selalu melibatkan kognitif. Kognisi sebagai keterampilan berpikir atau kemampuan intelektual yang digunakan dalam persepsi, memperoleh, memahami, dan menanggapi informasi yang disajikan kepada seseorang [3]. Kognitif berperan penting dalam hal pemikiran khususnya dalam hal matematika.

Matematika berisi tentang keteraturan pola dan struktur yang terorganisasi mulai dari unsur yang tidak didefinisikan, ke unsur yang didefinisikan, ke aksioma atau postulat dan akhirnya ke teorema [4]. Dalam hal ini tampak bahwa ketika mempelajari matematika memerlukan tingkat kemampuan berpikir yang tinggi. Tingkat kemampuan berpikir yang tinggi tidak bisa lepas dari kognitif yang tinggi pula. Sehingga matematika merupakan ilmu yang memerlukan tingkat kognitif yang tinggi. Ketika proses berpikir tentang permasalahan matematika, seseorang akan menggunakan kognitifnya secara maksimal. Penggunaan kognitif secara maksimal tentu melibatkan kehadiran dari fungsi kognitif. Fungsi kognitif sebagai sebuah proses mental yang memiliki makna khusus. Makna khusus diartikan untuk mengolah dan membangun informasi baru, serta menggunakan informasi baru tersebut pada situasi yang lebih kompleks [5]. Selanjutnya, fungsi kognitif merupakan aktivitas mental secara sadar meliputi berfikir, belajar, dan menggunakan bahasa [6]. Fungsi kognitif juga merupakan kemampuan atensi, memori, pertimbangan, pemecahan masalah, serta kemampuan eksekutif seperti merencanakan, menilai, mengawasi, dan melakukan evaluasi. Fungsi kognitif merupakan kemampuan seseorang untuk menerima, mengolah, menyimpan dan menggunakan kembali semua masukan sensorik secara baik [7]. Kehadiran fungsi kognitif seseorang dalam berpikir 
permasalahan matematika mengakibatkan berkembangnya fungsi kognitif seseorang tersebut.

Asumsi dasar dari program FIE, berdasarkan teori dan hasil penelitian oleh peneliti adalah tingkat intelegensi anak tidaklah statis [9]. Dengan asumsi dasar tersebut, Feuerstein menciptakan sebuah program baru yang membantu dalam meningkatkan kemampuan kognitif siswa. Instrumen ini mencari tahu kekurangan pada kemampuan berpikir dasar dalam hal memfasilitasi siswa dengan konsep, keterampilan, strategi, operasi, dan teknik penting yang dapat membuat siswa menjadi pembelajar yang baik. Secara sistematis, FIE memperkuat fungsi kognitif yang memungkinkan siswa untuk mendefinisikan masalah, membuat hubungan, dan meningkatkan keterampilan mereka [9]. Dalam hal ini tampak bahwa FIE membantu dalam meningkatkan kemampuan kognitif siswa.

Selain digunakan untuk mencari tahu kekurangan pada kemampuan berpikir dasar, melainkan juga bisa digunakan untuk mengidentifikasi fungsi kognitif yang tidak muncul. Hal ini sejalan dengan penelitian yang dilakukan [10] di lima negara yang meliputi Italia, Israel, Belgia, Chili, dan Kanada dengan jumlah peserta 188 siswa. Dalam penelitian tersebut menunjukkan bahwa setelah siswa mengikuti tes FIE, skor siswa tersebut mengalami peningkatan dibandingkan dengan sebelum mengikuti program tersebut karena FIE lebih mengintervensi siswa dalam meningkatkan kemampuan kognitifnya dengan cara memediasi siswa. FIE meningkatkan tingkat aktivitas intelektual seseorang dan persepsi mereka menjadi kognitif pribadi [11]. Dalam hal ini dapat disimpulkan bahwa FIE meningkatkan fungsi kognitif siswa secara maksimal.

FIE terdiri atas 14 instrumen yang berfokus pada ranah fungsi kognitif. Masingmasing instrumen dari FIE mengembangkan fungsi kognitif yang berbeda dari siswa. Namun dalam penelitian ini hanya akan digunakan tiga jenis instrument yang diadopsi dari 14 instrumen yang ada. Instrumen tersebut yaitu Pengorganisasian Titik, Progres Numeral, dan Pengelompokan. Ketiga instrumen ini dipilih karena instrumen ini pada dasarnya menggunakan matematika.

Dalam teori Piaget, usia antara 11 tahun hingga 15 tahun merupakan tahap perkembangan kognisi yang disebut tahap formal operation [7]. Pada usia ini anak-anak sudah masuk dalam jenjang pendidikan tingkat pertama (SMP). Pada tahap ini juga anakanak sudah bisa menangani situasi hipotesis, dan proses berpikirnya sudah tidak lagi bergantung pada hal-hal langsung dan riil. Pemikiran pada tahap ini semakin logis dan abstrak. Perkembangan kognitif anak diiringi dengan perkembangan fungsi kognitifnya sehingga pada tahap ini bisa dilihat seberapa besar perkembangan fungsi kognitifnya.

\section{METODE}

Penelitian ini merupakan penelitian deskriptif yaitu hasil pemataan fungsi kognitif dan kemampuan matematika siswa SMP dengan menggunakan Feuerstein's Instrumental Enrichment, maka pendekatan penelitian yang digunakan dalam penelitian ini adalah kualitatif. Penelitian ini dilaksanakan di SMP Negeri 2 Jombang pada semester genap tahun ajaran 2015/2016. Subjek penelitian pada penelitian ini adalah kelas VIII SMP sebanyak 32 siswa, yang terdiri atas 15 siswa laki-laki dan 17 siswa perempuan.

Subjek penelitian tersebut diberikan tes Feuerstein's Instrumental Enrichment dan dilanjutkan dengan wawancara berbasis tes untuk mengetahui fungsi kognitif yang muncul dari setiap subjek. Setiap subjek dilakukan wawancara selama 20 menit. Wawancara yang digunakan dalam penelitian ini adalah semi terstruktur. 
Instrumen tes Feuerstein's Instrumental Enrichment yang digunakan terdiri dari 3 jenis yaitu Pengorganisasian titik, Pengelompokan, dan Progres Numeral. Ketiga jenis tes Feuerstein's Instrumental Enrichment ini digunakan untuk mengetahui fungsi kognitif siswa yang muncul. Fungsi kognitif yang muncul tersebut dikategorikan dalam lima kategori yaitu "sangat baik", "baik", “cukup", "perlu dikembangkan”, dan "sangat perlu dikembangkan". Selanjutnya subjek penelitian diberikan tes Matematika untuk mengetahui tingkat kemampuan matematikanya. Dalam penelitian ini tingkat kemampuan matematika siswa dibagi menjadi tiga yaitu kemampuan matematika tinggi, kemampuan matematika sedang,dan kemampuan matematika rendah.

\section{HASIL DAN DISKUSI}

Berdasarkan penelitian yang telah dilakukan didapatkan:

\subsection{Hasil Pemetaan Fungsi Kognitif Siswa dengan Menggunakan FIE}

Hasil tes Feuerstein's Instrumental Enrichment jenis Pengorganisasian titik, didapatkan fungsi kognitif siswa semuanya muncul. Fungsi kognitif tersebut adalah (1) pendefinisian masalah; (2) pemilihan titik-titik yang relevan dengan bidang yang dicari; (3) perencanaan; (4) berpikir hipotetis dan penggunaan logika; dan (5) perilaku sumatif. Berikut ini diagram menyatakan fungsi kognitif siswa.

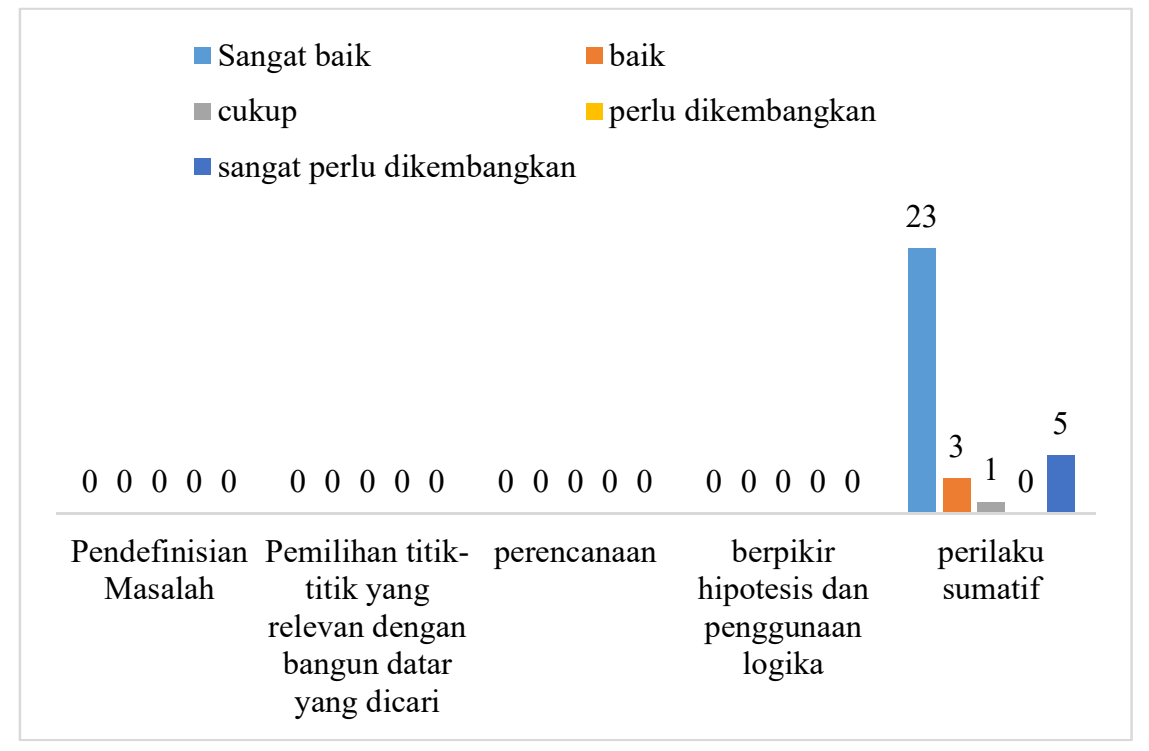

Gambar 1 Peta Fungsi Kognitif pada Pengorganisasian Titik

Gambar di atas menunjukkan bahwa tidak terdapat subjek yang berada pada fungsi kognitif "pendefinisian masalah", "pemilihan titik-titik yang relevan dengan bangun datar yang dicari”, "perencanaan”, "berpikir hipotesis dan penggunaan logika”. Dalam hal ini semua subjek berada pada fungsi kognitif yang terakhir yaitu fungsi kognitif "perilaku sumatif". Seperti yang tampak pada gambar di atas, fungsi kognitif "perilaku sumatif" muncul pada semua subjek. Namun fungsi kognitif tersebut berada pada empat kategori penilaian. Sebagian besar fungsi kognitif "perilaku sumatif" berkategori sangat baik, 
yaitu sebanyak 23 subjek, kategori baik sebanyak 3 subjek, kategori cukup sebanyak 1 subjek, dan kategori sangat perlu dikembangkan sebanyak 5 subjek. Untuk kategori penilaian perlu dikembangkan tidak ada. Semua subjek berada pada fungsi kognitif yang terakhir karena semua subjek dapat mengerjakan semua bagian dari tes yang diberikan

Hasil tes Feuerstein's Instrumental Enrichment jenis Pengelompokan, didapatkan fungsi kognitif siswa semuanya muncul. fungsi kognitif tersebut adalah (1) perilaku komparatif untuk memastikan kesamaan dan perbedaan, (2) pemilihan atribut yang relevan, dan (3) perilaku sumatif. Berikut ini diagram menyatakan fungsi kognitif siswa.

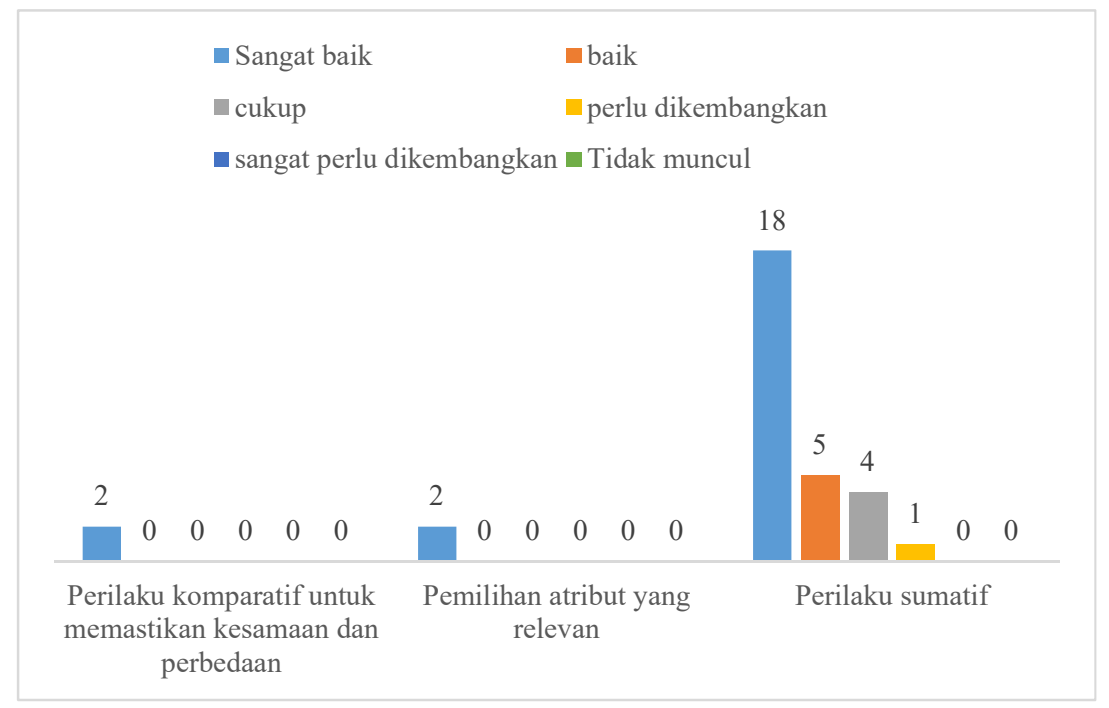

Gambar 2 Peta Fungsi Kognitif pada Pengelompokan

Fungsi kognitif yang muncul pertama adalah "perilaku komparatif untuk memastikan kesamaan dan perbedaan". Fungsi kognitif "perilaku komparatif untuk memastikan kesamaan dan perbedaan" hanya terdapat pada 2 subjek.

Fungsi kognitif yang muncul kedua adalah pemilihan atribut yang relevan. Seperti yang tampak pada Gambar 2, fungsi kognitif "pemilihan atribut yang relevan" hanya terdapat pada 2 subjek, yaitu S-57 dan S-61. Kedua subjek tersebut berada pada kategori fungsi kognitif "sangat baik".

Fungsi kognitif yang muncul ketiga adalah perilaku sumatif. Seperti yang tampak pada Diagram 4.2 gambar 2, fungsi kognitif "perilaku sumatif" muncul pada sebagian besar subjek. Fungsi kognitif tersebut berada pada empat kategori penilaian. Sebagian besar fungsi kognitif "perilaku sumatif" berkategori sangat baik, yaitu sebanyak 18 subjek, kategori baik sebanyak 5 subjek, kategori cukup sebanyak 4 subjek, dan kategori perlu dikembangkan sebanyak 1 subjek. Untuk kategori penilaian sangat perlu dikembangkan tidak ada

Hasil tes Feuerstein's Instrumental Enrichment jenis Progres Numeral, didapatkan fungsi kognitif siswa semuanya muncul. fungsi kognitif tersebut adalah (1) penggunaan isyarat yang relevan seperti indeks (tempat bilangan dalam deret), dan (2) proyeksi hubungan antar suku dalam deret. Berikut ini diagram menyatakan fungsi kognitif siswa. 


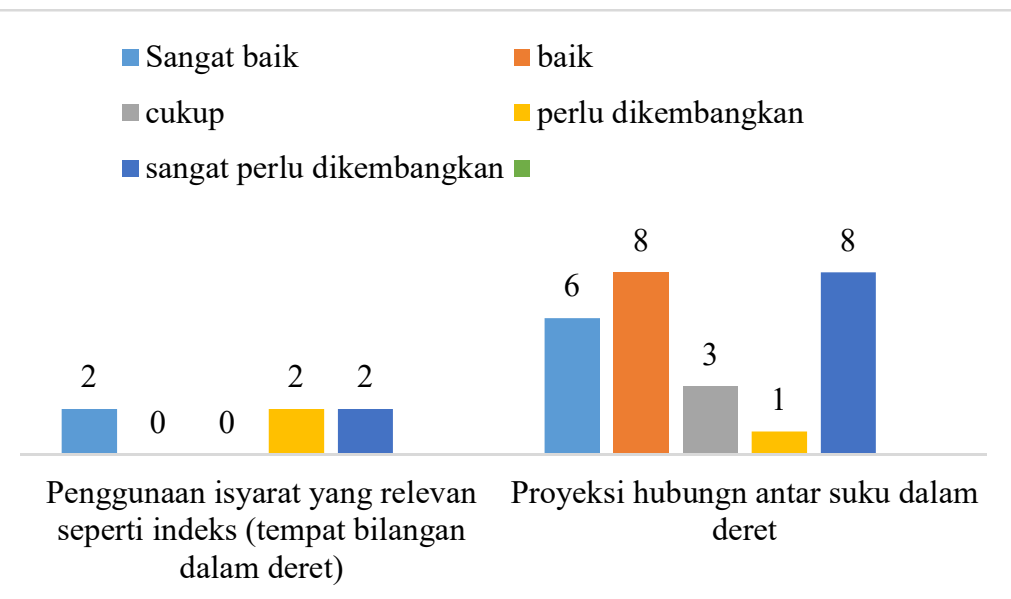

Gambar 3 Peta Fungsi Kognitif pada Progres Numeral

Berdasarkan hasil pemetaan yang terdapat pada Diagram di atas, diketahui bahwa fungsi kognitif yang muncul adalah (1) penggunaan isyarat yang relevan seperti indeks (tempat bilangan dalam deret), dan (2) proyeksi hubungan antar suku dalam deret. Namun kedua fungsi kognitif yang muncul pada subjek berada pada kategori penilaian yang berbeda. Kategori peniaian fungsi kognitif tersebut adalah (1) sangat baik, (2) baik, (3) cukup, (4) perlu dikembangkan, dan (5) sangat perlu dikembangkan.

Fungsi kognitif yang muncul pertama adalah "penggunaan isyarat yang relevan seperti indeks (tempat bilangan dalam deret)". Seperti yang ada pada Gambar 3, fungsi kognitif "penggunaan isyarat yang relevan seperti indeks (tempat bilangan dalam deret)" hanya terdapat pada 6 subjek. Fungsi kognitif tersebut berada pada kategori penilaian sangat baik, perlu dikembangkan, dan sangat perlu dikembangkan. Hanya saja sebagian besar fungsi kognitif "penggunaan isyarat yang relevan seperti indeks (tempat bilangan dalam deret)" berkategori "sangat baik", yaitu sebanyak 2 subjek, berkategori "perlu dikembangkan" sebanyak 2 subjek, dan berkategori "sangat perlu dikembangkan" sebanyak 2 subjek.

Fungsi kognitif yang muncul kedua adalah "proyeksi hubungan antar suku dalam deret". Seperti yang tampak pada Diagram 4.3, fungsi kognitif "proyeksi hubungan antar suku dalam deret" terdapat pada sebagian besar subjek. Fungsi kognitif tersebut berada pada semua kategori penilaian. Fungsi kognitif "proyeksi hubungan antar suku dalam deret" berkategori sangat baik, yaitu sebanyak 6 subjek, kategori baik sebanyak 8 subjek, kategori cukup sebanyak 3 subjek, kategori perlu dikembangkan sebanyak 1 subjek, dan kategori sangat perlu dikembangkan sebanyak 8 .

\subsection{Hasil Pemetaan Kemampuan Matematika Siswa dengan Memperhatikan Fungsi Kognitif}

Hasil tes Matematika dengan memperhatikan fungsi kognitif pada pengorganisasian titik dapat dinyatakan dalam diagram berikut ini. 


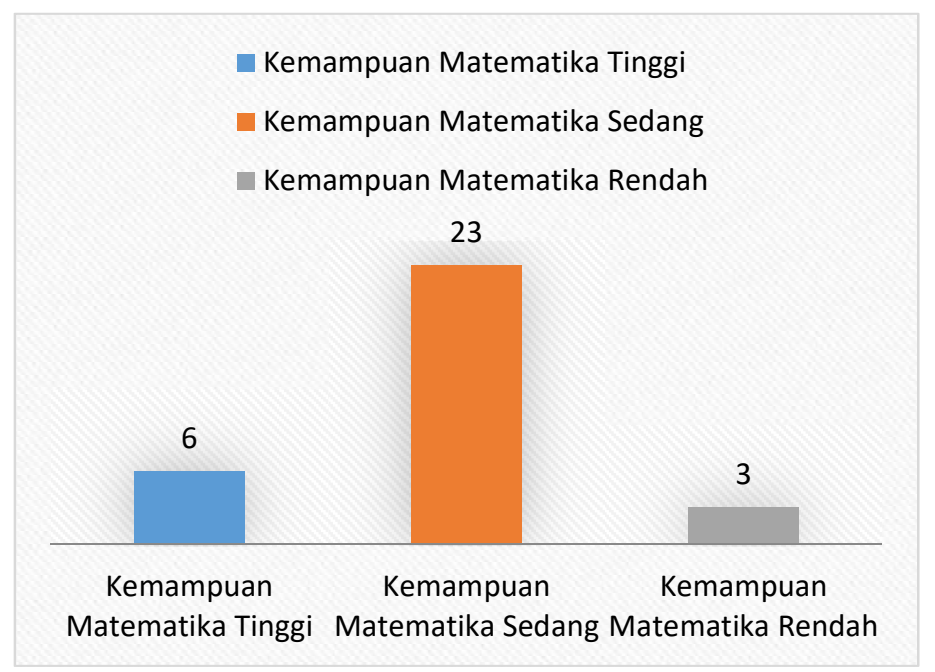

Gambar 4 Peta Kemampuan Matematika pada Pengorganisasian Titik

Berdasarkan hasil pemetaan yang terdapat pada Gambar 4, diketahui bahwa fungsi kognitif yang meliputi: (1) pendefinisian masalah, (2) pemilihan titik-titik yang relevan dengan bantuan bangun datar yang dicari, (3) perencanaan, (4) berpikir hipotesis dan penggunaan logika, dan (5) perilaku sumatif. Namun dalam hal ini semua subjek hanya terdapat dalam fungsi kognitif "perilaku sumatif”. Dari 32 subjek tersebut muncul, terlihat bahwa sebanyak 6 subjek mempunyai kemampuan matematika tinggi, 23 subjek mempunyai kemampuan matematika sedang, dan 3 subjek mempunyai kemampuan matematika rendah.

Hasil tes Matematika dengan memperhatikan fungsi kognitif pada pengelompokan dapat dinyatakan dalam diagram berikut ini.

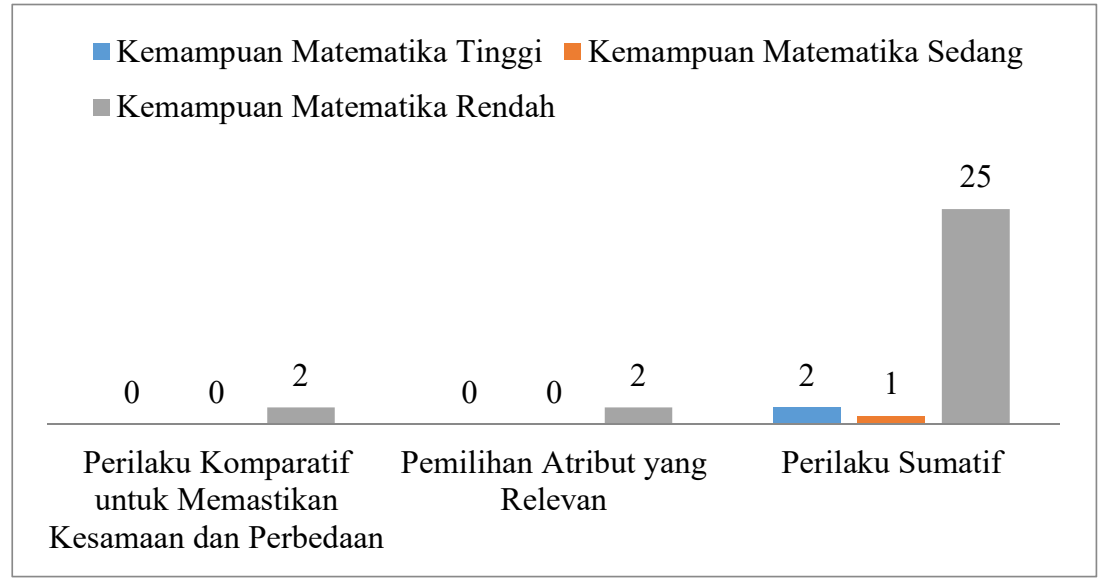

Gambar 5 Peta Kemampuan Matematika pada Pengelompokan

Berdasarkan hasil pemetaan yang terdapat pada Gambar 5, diketahui bahwa fungsi kognitif "Perilaku komparatif untuk memastikan kesamaan dan perbedaan" terdapat pada 2 subjek. Dari 32 subjek dengan fungsi kognitif "Perilaku komparatif untuk memastikan 
kesamaan dan perbedaan", 2 subjek tersebut termasuk ke dalam kemampuan matematika rendah.

Di samping itu, diketahui bahwa fungsi kognitif "Pemilihan atribut yang relevan" terdapat pada 2 subjek. Dari 2 subjek yang fungsi kognitif "Pemilihan atribut yang relevan", kedua subjek tersebut termasuk kedalam kemampuan matematika rendah.

Selain itu, diketahui bahwa fungsi kognitif "Perilaku sumatif" terdapat pada 28 subjek. Dari 28 subjek yang fungsi kognitif "Perilaku sumatif”, terpecah menjadi 2 subjek berkemampuan matematika tinggi, 1 subjek berkemampuan matematika sedang, dan 25 subjek berkemampuan matematika rendah.

Hasil tes Matematika dengan memperhatikan fungsi kognitif pada progress numeral, dapat dinyatakan dalam diagram berikut ini.

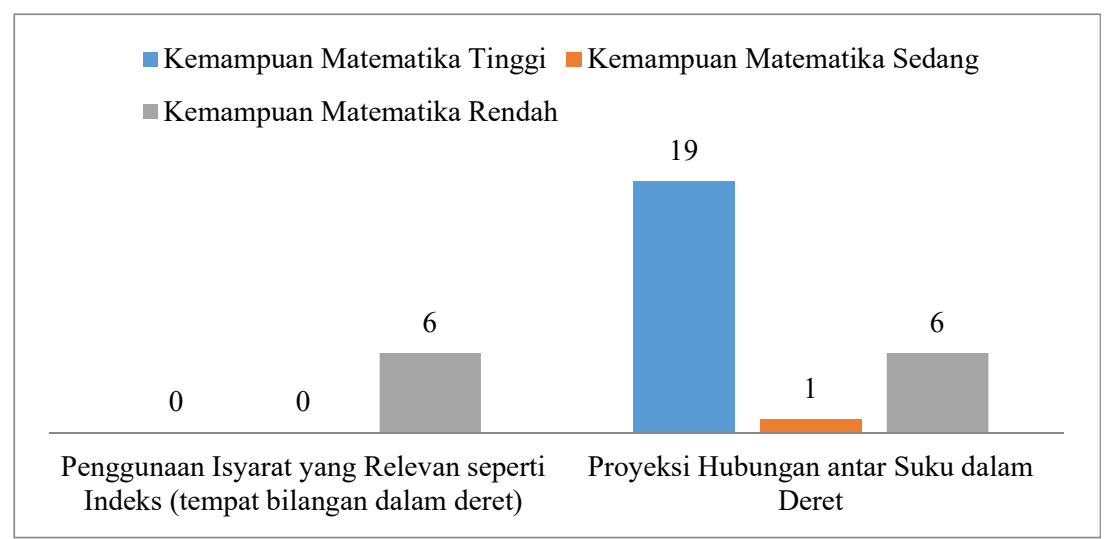

Gambar 6 Peta Kemampuan Matematika pada Progres Numeral

Berdasarkan hasil pemetaan yang terdapat pada Gambar 6 diketahui bahwa fungsi kognitif "Penggunaan isyarat yang relevan seperti indeks (tempat bilangan dalam deret)" terdapat pada 6 subjek. Dari 6 subjek dengan fungsi kognitif "Penggunaan isyarat yangrelevn seperti indeks (tempat bilangan dalam deret)", terlihat bahwa keenam subjek tersebut termasuk ke dalam kategori kemampuan matematika rendah.

Berdasarkan hasil pemetaan yang terdapat pada Gambar 6, diketahui bahwa fungsi kognitif "Proyeksi Hubungan antar suku dalam deret" muncul pada 26 subjek. Dari 26 subjek yang fungsi kognitif "Proyeksi Hubungan antar suku dalam deret", terbagi menjadi 19 subjek berkemampuan matematika tinggi, 1 subjek berkemampuan matematika sedang, dan 6 subjek berkemampuan matematika rendah.

\section{Kesimpulan}

a. Peta Fungsi Kognitif Siswa SMP

Peta Fungsi Kogntif Siswa dengan Menggunakan Feuerstein's Instrumental Enrichment (FIE) jenis Pengorganisasian titik menunjukkan bahwa lima fungsi kognitif dari subjek semuanya muncul. Dari lima fungsi kognitif yang muncul, sebesar 71,875\% fungsi kognitif dalam kategori "Sangat Baik", sebesar 14,375\% fungsi kogntitf dalam kategori "Baik", sebesar 3,75\% fungsi kognitif siswa dalam kategori "Cukup", sebesar 5\% fungsi kognitif siswa dalam kategori "Perlu 
Dikembangkan", dan sebesar 5\% fungsi kognitif siswa dalam kategori "Sangat Perlu Dikembangkan". Sedangkan sebesar $0 \%$ darisiswa yang fungsi kognitifnya tidak muncul.

Peta Fungsi Kogntif Siswa dengan Menggunakan Feuerstein's Instrumental Enrichment (FIE) jenis Pengelompokan menunjukkan bahwa tiga fungsi kognitif dari sebagian besar subjek semuanya muncul dan sebagian kecil tidak muncul. Dari tiga fungsi kognitif yang muncul, sebesar 72,92\% fungsi kognitif dalam kategori "Sangat Baik", sebesar 10,41\% fungsi kogntitf dalam kategori "Baik", sebesar 5,21\% fungsi kognitif siswa dalam kategori "Cukup", sebesar 5,21\% fungsi kognitif siswa dalam kategori "Perlu Dikembangkan", dan sebesar 0\% fungsi kognitif siswa dalam kategori "Sangat Perlu Dikembangkan". Sedangkan sebesar 6,25\% darisiswa yang fungsi kognitifnya tidak muncul.

Peta Fungsi Kogntif Siswa dengan Menggunakan Feuerstein's Instrumental Enrichment (FIE) jenis Progres Numeral menunjukkan bahwa dua fungsi kognitif dari sebagian besar subjek semuanya muncul dan sebagian kecil tidak muncul. Dari dua fungsi kognitif yang muncul, sebesar 46,875\% fungsi kognitif dalam kategori "Sangat Baik", sebesar 15,625\% fungsi kogntitf dalam kategori "Baik", sebesar 6,25\% fungsi kognitif siswa dalam kategori "Cukup", sebesar 6,25\% fungsi kognitif siswa dalam kategori "Perlu Dikembangkan", dan sebesar 15,625\% fungsi kognitif siswa dalam kategori "Sangat Perlu Dikembangkan". Sedangkan sebesar 9,375\% dari siswa yang fungsi kognitifnya tidak muncul.

b. Peta Kemampuan Matematika Siswa dengan Memperhatikan Fungsi Kognitif

Peta kemampuan matematika siswa dengan memperhatikan fungsi kognitif pada FIE jenis Pengorganisasian Titik menunjukkan bahwa lima fungsi kognitif dari subjek semuanya muncul. Dari lima fungsi kognitif yang muncul, sebesar 16\% dari subjek termasuk dalam kategori kemampuan matematika tinggi, sebesar 34\% termasuk dalam kategori kemampuan matematika sedang,dan sebesar 50\% termasuk dalam kategori matematika rendah. Sedangkan sebesar $0 \%$ dari siswa yang fungsi kognitifnya tidak muncul.

Peta kemampuan matematika siswa dengan memperhatikan fungsi kognitif pada FIE jenis Pengelompokan menunjukkan bahwa tiga fungsi kognitif dari subjek sebagian besar muncul dan sebagian kecil tidak muncul. Dari tiga fungsi kognitif yang muncul, sebesar $15,625 \%$ dari subjek termasuk dalam kategori kemampuan matematika tinggi, sebesar 34,375\% termasuk dalam kategori kemampuan matematika sedang,dan sebesar 40,625\% termasuk dalam kategori matematika rendah. Sedangkan sebesar 9,375\% dari siswa yang fungsi kognitifnya tidak muncul, termasuk dalam kategori kemampuan matematika rendah.

Peta kemampuan matematika siswa dengan memperhatikan fungsi kognitif pada FIE jenis Progress Numeral menunjukkan bahwa tiga fungsi kognitif dari subjek sebagian besar muncul dan sebagian kecil tidak muncul. Dari tiga fungsi kognitif yang muncul, sebesar 15,625\% dari subjek termasuk dalam kategori kemampuan matematika tinggi, sebesar $31,25 \%$ termasuk dalam kategori kemampuan matematika sedang,dan sebesar 34,375\% termasuk dalam kategori matematika rendah. Sedangkan sebesar $18,75 \%$ dari siswa yang fungsi kognitifnya tidak muncul, 
dengan kriteria sebanyak $15,625 \%$ termasuk dalam kategori matematika rendah dan $3,125 \%$ termasuk dalam kategori matematika sedang.

\section{DaftarPustaka}

[1] Ruggiero, V. R. 1998. The Art of Thinking: A Guide to critical and Creative Thought. New York: Long Man, An Imprint of Addison Wesley Lonfman, Inc.

[2] Soemanto, W. 2007. Psikologi Pendidikan. Jakarta: PT Asdi Mahasatya

[3] Alston, Chevette. What is Cognitive Dysfunction? - Causes, Symptoms \& Treatment. Diakses tanggal 7 Februari 2015 dari http://educationportal.com/academy/lesson/what-is-cognitive-dysfunction-causes-symptomstreatment.html

[4] Ruseffendi, E.T. 1991. Materi Pokok Pendidikan Matematika III. Jakarta: Universitas Terbuka

[5] Kinard, James. 2007. Method and Aparatus for Creating Rigourus Mathematical Thinking. $\quad$ Diunduh $20 \quad$ November $2014 \quad$ dari www.umanitoba.ca/unevoc/conference/papers/kinard.pdf

[6] Rizzo, M. \& Eslinger, Paul J. 2004. "Principles and Practice of Behavioral Neurologi and Neuropsychology”. Pp 615-634, Philadelpia PA: WB Saunders Company

[7] Kabil. 2012. Fungsi Kognitif. Diakses tanggal 7 Februari 2015 dari http://bedande.blogspot.sg/2012/01/fungsi-kognitif.html

[8] Hergenhahn, B. R., \& Olson, M. H. 2008. Theories of Learning (Teori Belajar). Jakarta: Prenada Media Grup

[9] Feuerstein, Reuven. 2012. Mediated Learneng Experience, Instrumental Enrichment, and the Learning Propensity Assessment Device. Diunduh 20 November 2014 dari www.icdl.com/graduate/documents/Chapter22.pdf

[10] Kozulin, A. Et al. 2009. Cognitive modifiability of children with developmental disabilities. Article in press, 9

[11] Todor, O. A. 2013. Feuerstein Instrumental Enrichment Program. International Conference of Scientific Paper (hal. 10-13). Brasov: Spiru Haret University press. 